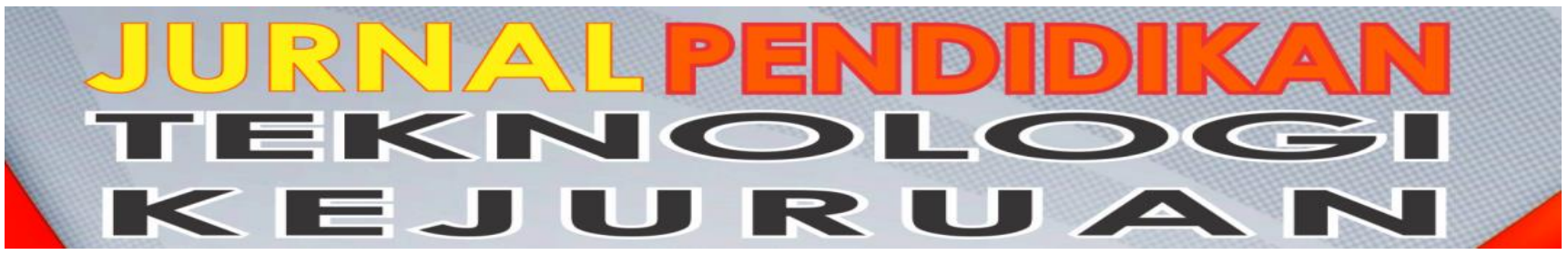

Vol. 4, No. 2, May 2021

P-ISSN: 2621-3273

E-ISSN: 2621-1548

\title{
Career Understanding, Motivation, and Students' Decision-Making to Choose Vocational High School (SMK) in Non-Industrial Area
}

\author{
Hery Wiharja $\mathrm{MS}^{1 *}$, Ary Firnanda ${ }^{2}$ \\ ${ }^{1}$ Teknologi Pengelasan Logam, Akademi Komunitas Negeri Aceh Barat \\ ${ }^{2}$ Instalasi Pemeliharaan Jaringan Listrik, Akademi Komunitas Negeri Aceh Barat \\ *Corresponding author, e-mail: wiharja.ms@aknacehbarat.ac.id ${ }^{1}$
}

\begin{abstract}
This study aims to measure and describe students' decision-making to choose Vocational High School (SMK) in terms of their career understanding and motivation. The subjects of this study were 135 Year 9 students in five SMK throughout Southwest Aceh Regency. The total sampling method was used to choose the subjects from the entire population. Furthermore, the data were analysed using correlation analysis between variables partially and simultaneously with ANOVA (F test). The results of the partial correlation analysis show that the career understanding variable has a significant influence on students' decision-making to choose SMK with $\mathbf{r}_{\text {count }}=0.411$ at a significance level of $\mathbf{0 . 0 5}$. In addition, the motivation variable also has a significant influence on decision-making to choose SMK with $\mathbf{r}_{\text {count }}=\mathbf{0 . 3 7 5}$. Simultaneously, career understanding and motivation significantly affect choosing SMK with $F_{\text {count }}=19.850$ and $F_{\text {table }}=3.06\left(F_{\text {count }}>F_{\text {table }}\right)$. This study results indicate that career understanding variables consist of work planning, work exploration and knowledge of the world of work. In contrast, the motivation variables consist of intrinsic and extrinsic motivation, which could be the basis for students' decision making.
\end{abstract}

Keywords: career understanding, motivation, decision-making

\section{INTRODUCTION}

High school is the beginning of a student's career path. Choosing a Senior High School (SMA) or Vocational High School (SMK) is reasonable after students understand the career path and have strong motivation or reasons.

Choosing an SMK with the hope of having qualified skills and being ready to work is an ideal concept if a prospective SMK student has understood the concept of a career well. Knowledge and understanding of career planning for Junior High School (SMP) graduates are classified in a very narrow category (Sitompul 2018). The lack of SMP graduates' career understanding hinder students in making good high school selection decisions. Suppose SMP graduates do not understand the concept of a career when choosing SMK, these students will find it challenging to understand the working life and produce SMK graduates who are less ready to work after graduation (Anggraeni, Putro, and Putro 2015).

Based on data from Statistics Indonesia (BPS) per August 2019, the National Open Unemployment Rate (Tingkat Pengangguran Terbuka/TPT) places SMK graduates as the highest unemployed with a percentage of $10.42 \%$ (BPS 2020). Employing SMK graduates will be very difficult, mainly if the SMK is in a nonindustrial area.

The non-industrial area in this research is intended for the selection of the research location. The Southwest Aceh Regency had been chosen as a research location due to the number of industries listed in the Department of Cooperatives, Small and MediumSized Enterprises (SMEs), Trade and Industry are not comparable to the total number of absorbed workers. The total registered industries are 721 SMEs with a total of 2,468 workers. Based on the average, each industry could only accommodate three workers.

Analysis of job opportunities in the industry could be considered in deciding to continue studies in SMA or SMK. In addition, decision-making of high school choice also needs encouragement or motivation. There are various factors identified from the motivation of SMP graduates to choose SMA/SMK, such as the parents' choice, friends, facilities, and career prospects (Devisanti and Muti'ah 2014). A factor that must be a particular focus is the jobs/industries ready to 
accommodate SMK graduates in the area/district (Fitriantie, Sulistyarini, and Parijo 2014).

\section{METHOD}

This study was designed using a correlational method with a quantitative descriptive approach. This method is intended to determine the level of relationship and influence between independent variables (career understanding and motivation) on the dependent variable (decision to choose SMK in Non-Industrial Regions).

This research was conducted in five SMKs in Southwest Aceh Regency for three months, from April to June. The population in this study was Year 9 students of the 2021/2022 Academic Year and the sample was the entire population (total sampling) of 135 students.

Furthermore, the data was collected using a closed questionnaire with dichotomous items. The questionnaire consists of questions that include career understanding variables (work planning, career exploration and knowledge of the world of work), motivation variables (intrinsic and extrinsic motivation) and decision making variables (based on rationality, facts and experience).

The data were analyzed using Partial Correlation with Pearson Analysis to reveal the criteria for the relationship. Meanwhile, to answer the research hypothesis, the ANOVA test (F test) was used to discover the relationship or influence of the independent variables towards the dependent variable simultaneously.

\section{RESULTS}

A field study to the Department of Cooperatives, SMEs, Industry and Trade in Southwest Aceh Regency results in data on the comparison between the number of industries and workers as presented in Figure 1.

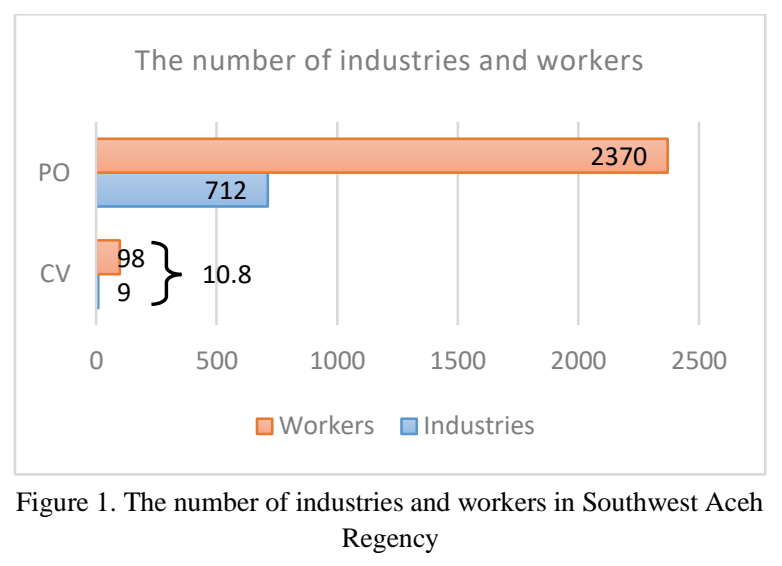

The data in Figure 1 show that Southwest Aceh Regency is lack industries. This fact could be seen from the number of Limited Partnership (CV), which is only nine and only able to absorb 98 workers with an average of 10.8 people. In comparison, Individual Proprietorship (PO) amounted to 712 industries that could absorb an average of three labors.

The small number of job opportunities in the industrial sector in the Southwest Aceh Regency could have implications for students' decisions to continue their education at SMK. This phenomenon is because SMK is projected to produce graduates ready to work, including the industrial sector (Wiharja 2018).

The data distribution from the research results in five SMKs throughout Southwest Aceh Regency is described in Table 1.

\begin{tabular}{ccc} 
& \multicolumn{3}{c}{ Table 1. Demographic Data } \\
\hline & Demographics & Quantity \\
\hline Gender & Boy & 79 \\
& Girl & 56 \\
\hline Age & $14-15$ & 20 \\
& $16-17$ & 106 \\
& $18-19$ & 9 \\
\hline Parents' job & Farmer & 68 \\
& Fisherman & 12 \\
& Private & 43 \\
& Entrepreneur & 11 \\
& Civil Servant & 1 \\
\hline Previous & SMP & 103 \\
School & Islamic Junior & 30 \\
& High School & \\
& (MTs) & \\
& Boarding & 2 \\
& school &
\end{tabular}

Based on Table 1, it can be seen that $78.51 \%$ or 106 of the total students over the age range 16-17-year-old and $58.52 \%$ or 79 of students is dominated by boys. 


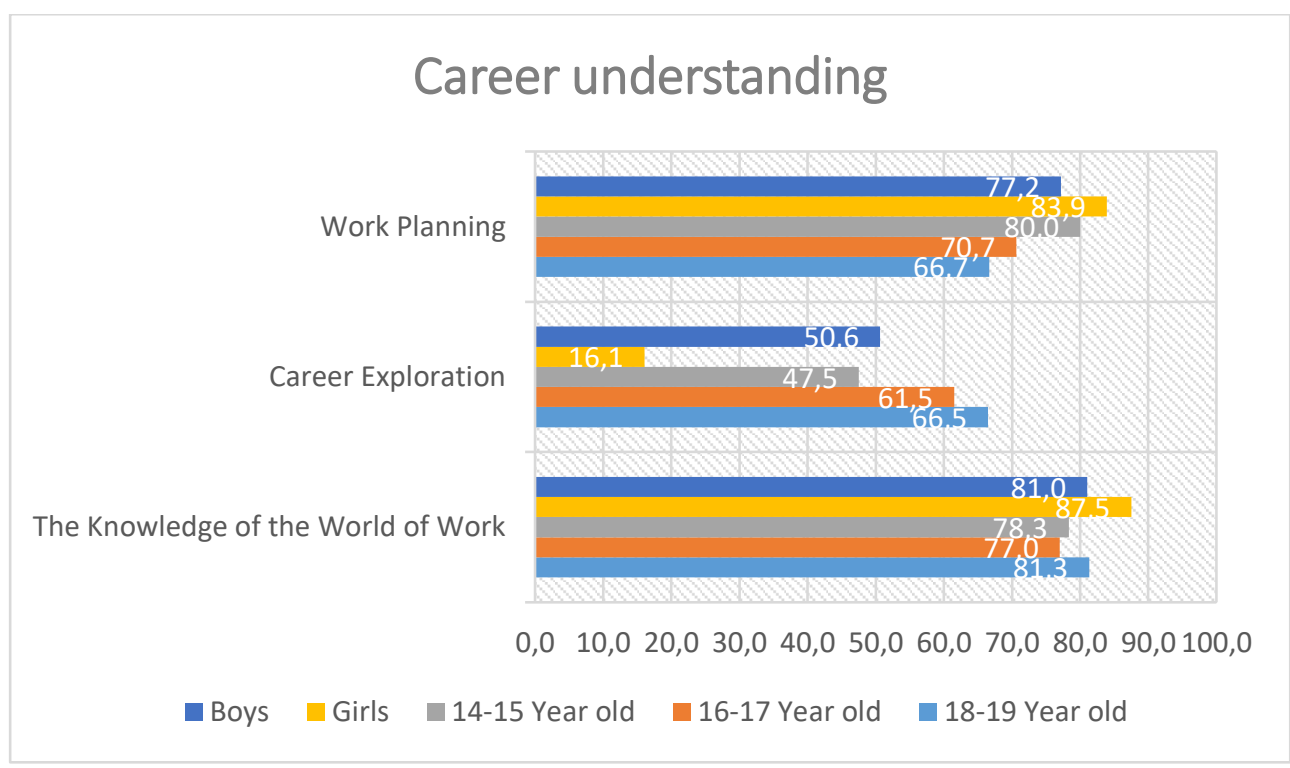

Figure 2. Career understanding

Data in Figure 2 reveal that the boys understand the career before choosing SMK, with an average percentage of $69.7 \%$ of total three indicators. From the three indicators in the career understanding variables, the knowledge about the world of work has the highest percentage of $81 \%$. In contrast, the career exploration indicator has the lowest percentage of $50.6 \%$.

Moreover, girls have a $62.5 \%$ average level of career understanding. The indicator of knowledge about the world of work for the girls has the highest percentage of $87.5 \%$, while the career exploration indicator has the lowest percentage of $16.1 \%$.

The samples in this study were grouped into three based on their age range to discover their level of career understanding. The 18-19 year age range had a high average level of career understanding, $71.5 \%$, whereas the 14-15 year age range had an average of $68.6 \%$ career understanding. The 16-17-year-old had a career understanding level of $69.7 \%$.

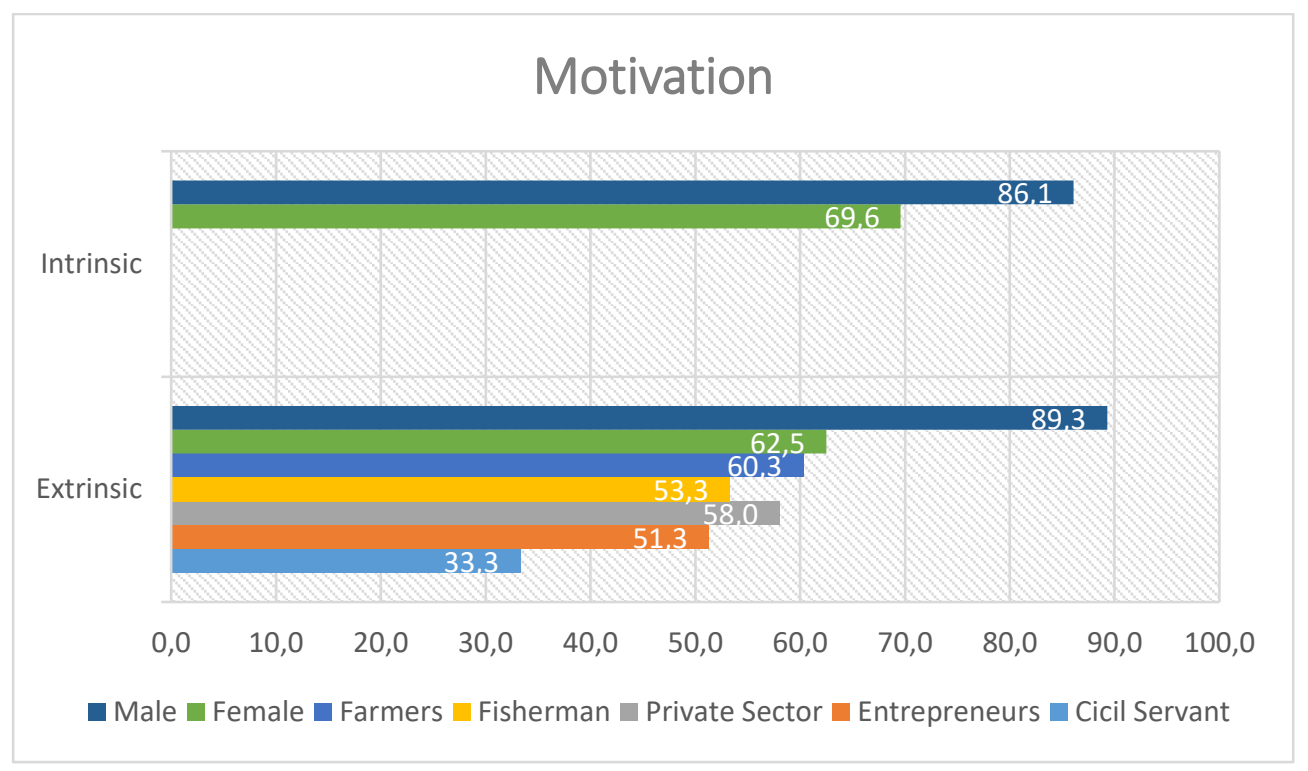

Figure 3. Motivation variables

The research data in motivation variables found that boys have high motivation levels to continue to SMK with an average percentage of $87.7 \%$ of total two indicators. The Extrinsic motivation of boys has a high percentage of $89.3 \%$, while the intrinsic motivation is $86.1 \%$. 
Meanwhile, girls have an average level of motivation of $66.05 \%$, with intrinsic motivation having a higher percentage of $69.6 \%$ than the extrinsic motivation of $62.5 \%$. The students' motivation to choose SMK is also seen from their extrinsic motivation, namely their parents' jobs. Five parental occupations based on research data are farmers, fishermen, private sector, entrepreneurs, and civil servants (PNS). The five types of parental occupation encourage or motivate students at different levels, as shown in Table 2.

Table 2. Percentage of extrinsic motivation based on parents' occupation

\begin{tabular}{ccc}
\hline Work & Quantity & $\begin{array}{c}\text { Percentage } \\
(\%)\end{array}$ \\
\hline Farmer & 68 & 60.3 \\
Fisherman & 12 & 53.3 \\
Private & 43 & 58 \\
Entrepreneur & 11 & 51.3 \\
Civil Servant & 1 & 33.3 \\
\hline
\end{tabular}

Based on that data in Table 2, 68 parents who work as farmers give the highest extrinsic motivation compared to parents with other jobs with a percentage of $60.3 \%$.

The relationship between the career understanding variables and students' motivation to choose an SMK and the strength of the relationship between $\mathrm{X} 1$ and $\mathrm{X} 2$ variables towards the $\mathrm{Y}$ variable can be seen in Table 3.

Table 3. Correlation analysis between $\mathrm{X} 1, \mathrm{X} 2$ variables towards $\mathrm{Y}$ variable

\begin{tabular}{|c|c|c|c|c|}
\hline \multicolumn{5}{|c|}{ Correlations } \\
\hline & & $\begin{array}{c}\text { Career } \\
\text { Understanding }\end{array}$ & Motivation & $\begin{array}{l}\text { Decision- } \\
\text { making }\end{array}$ \\
\hline \multirow[t]{3}{*}{ Career Understanding } & Pearson Correlation & 1 & $.342^{* *}$ & $.411^{* *}$ \\
\hline & Sig. (2-tailed) & & .000 & .000 \\
\hline & $\mathrm{N}$ & 135 & 135 & 135 \\
\hline \multirow[t]{3}{*}{ Motivation } & Pearson Correlation & $.342^{* *}$ & 1 & $.375^{* *}$ \\
\hline & Sig. (2-tailed) & .000 & & .000 \\
\hline & $\mathrm{N}$ & 135 & 135 & 135 \\
\hline \multirow[t]{3}{*}{ Decision-making } & Pearson Correlation & $.411^{* *}$ & $.375^{* *}$ & 1 \\
\hline & Sig. (2-tailed) & .000 & .000 & \\
\hline & $\mathrm{N}$ & 135 & 135 & 135 \\
\hline
\end{tabular}

The results of the correlation analysis with Pearson correlation using the SPSS application can be interpreted that partially each independent variable has a relationship and influence on the dependent variable. This result can be seen from the $r_{\text {count }}$ value between the Career Understanding variable (X1) and the Decision-Making variable (Y) of 0.411 . While the $\mathrm{r}_{\text {table }}$ with $\mathrm{N}=135$ at a significance of 0.05 obtained a value of 0.168 . In comparison between $r_{\text {count }}$ and $r_{\text {table }}$, so $r_{\text {count }}$ $(0.411)>r_{\text {table }}(0.168)$ means that students' career understanding has a significant relationship or has an influence on decision-making in choosing SMK in non-industrial areas.

The same result is also presented between the relationship of the Motivation variable (X2) to Decision-Making $(Y)$ with $r_{\text {count }}(0.375)>r_{\text {table }}(0.168)$. This result means that the students' motivation has a significant relationship or influences decision-making to choose SMK in non-industrial areas. Meanwhile, to measure the level of relationship or effect between the independent variables (X1 and $\mathrm{X} 2$ ) simultaneously towards the $\mathrm{Y}$ variable, the ANOVA test (F-test) was used by comparing the $\mathrm{F}_{\text {count }}$ and $\mathrm{F}_{\text {table }}$.

Table 4. Simultaneous F-Test of Independent Variables on Dependent Variable

\begin{tabular}{cccccr}
\hline \multicolumn{5}{c}{ ANOVA $^{\text {a }}$} \\
\hline \multirow{2}{*}{ Model } & Sum of & df & Mean & F \\
& & Squares & & Square & \\
\hline 1 & Regression & 23.402 & 2 & 11.701 & 19.8 \\
& & & & & 50
\end{tabular}




\begin{tabular}{lrrr} 
Residual & 77.812 & 132 & .589 \\
Total & 101.215 & 134 & \\
\hline
\end{tabular}

a. Dependent Variable: Decision-Making

b. Predictors: (Constant), Motivation, Career Understanding

Table 4 is the result of the F-Test to measure the relationship or influence of the Career Understanding (X1) and Motivation (X2) variables simultaneously on the Decision-Making variable (Y) of students who choose to continue their education to SMK in nonindustrial areas. Based on the F-test results, $F_{\text {count }}$ is equal to 19.850 , compared to $F_{\text {table }}$ with a value of 3.06 , then $F_{\text {count }}(19.850)>F_{\text {table }}(3.06)$. The results of this comparison answer the research hypothesis that Career Understanding (X1) and Motivation (X2) have a significant relationship or influence on Students' Decision-Making (Y) to continue their education to SMK in non-industrial areas.

\section{DISCUSSION}

Many variables influence a student in choosing their school. It could be that the destination school is part of stages towards a coveted career or indeed because of the economic demands of the family that encourage them to go to certain schools to get a job after graduating from school. Likewise, with the decisions of SMP graduates who have a 14-19 years age range with all the causal factors that result in a decision to continue their education to SMK or SMA.

This research reveals two of the many variables that cause students to decide to continue their education at SMK: their career understanding and motivation.

Career understanding is a condition where individuals could develop their circumstances in making career decisions. In Counselling for Career Development, Tolbert stated that the understanding of the career is a structured program for helping students understand themselves and study the world of work to gain experience that will help make a career decision (Wardani and Trismani 2017).

The research findings based on the analysis of questionnaires that have been filled out by 135 students of Year 9 show that students' understanding of careers and the world of work is quite good with an average percentage of $69.7 \%$ of boys and $62.5 \%$ of girls. There are three indicators to measure students' career understanding: work planning, career exploration, and knowledge of the world of work (Sitompul 2018).
Furthermore, knowledge about the world of work has the highest average percentage, $81 \%$ of boys and $87.5 \%$ of girls. It means that overall, students know about various types of work and their derivatives, job risks and future job opportunities that are in line with the majors they currently choose in SMK.

The lowest average percentage is a career exploration indicator with $50.6 \%$ boys and $16.1 \%$ girls. This percentage indicates a lack of initiative by both boys and girls in digging up more information about career potential from various sources. It is also because the students rarely consult about their career direction, interests, and talents with counselling teachers during junior high school before deciding to continue their education at SMK.

From age on career understanding, Year 9 students in SMK aged 18-19 years have the highest average career understanding level of $71.5 \%$ compared to students aged 14-15 and 16-17 years. It means that age maturity is directly in line with thinking maturity, understanding and planning a future career (Wiharja, Rahayu, and Rahmiyati 2020).

The second variable measured in the study is motivation with intrinsic and extrinsic motivation. Intrinsic motivation arises from a person's behaviour to do or achieve something for him and does not need external stimulation. In contrast, extrinsic motivation is motivation or stimulation that comes from outside of a person and encourages that person to do or achieve something (Maulana 2015).

The study result reveals that the average boys' motivation is high, with $87.7 \%$ and $66.6 \%$ girls. The high motivation of boys is the dominance of the high external motivation. The motivation was stimulated by suggestions and input from friends and family to choose an SMK so that they could immediately get a job after graduation. This strong motivation also arises from the desire to help the family economy by directly working after graduating from SMK (Lestari and Mudzakkir 2016) (Maulana et al. 2020). Meanwhile, the student's intrinsic motivation is based on their interest in the skills offered by the SMK and the excellent image of the SMK in terms of infrastructure, learning methods, laboratory equipment and the image of SMK alumni who can work immediately after graduating from SMK. The students' decision-making to continue their education at SMK results from a good career understanding and high motivation. 
Based on the partial correlation analysis results, it can be concluded that the career understanding of each student to work planning and employment opportunities in the future are arranged well and directed. It facilitates the students in the decision to continue high school at SMK. The potential to get a job after graduating from SMK is greater than graduating from SMA, both as a workforce and entrepreneur. In analysis, career understanding has a significant relationship or influence on decisionmaking by students in choosing the high school to SMK.

However, the results of the correlation analysis of motivational variables show that intrinsic and extrinsic motivation is related or significantly influences the students' decision-making to choose SMK. The encouragement of parents and closest friends becomes a strong influence on the decision-making.

\section{CONCLUSION}

Choosing an SMK is part of students' study and external incentives that affect them. Careful analysis of the work profession in the future and the hope that it will be easy to get a job after graduating from SMK are also supporting factors in decision-making.

The decision to choose SMK does not significantly affect the small number of job opportunities in the industries in the Southwest Aceh Regency. The slow industrial growth and the low level of labour demand do not dampen the interest of Junior High School graduates to continue their education at SMK.

\section{REFERENCES}

Anggraeni, H. G., S. C. Putro, and Y. Putro. 2015. "Studi Pemahaman Karier Dan Relevansi Praktikum Terhadap Kesiapan Kerja Pada Siswa SMK.” Jurnal Teknologi Elektro Kejuruan (TEKNO) 24(2):1-8.

BPS. 2020. "Keadaan Ketenagakerjaan Indonesia Agustus 2019.” Badan Pusat Statistik XXiI, 05 N(91):1-20.

Devisanti, Nova, and Titik Muti'ah. 2014. "Hubungan Antara Minat Dengan Motivasi Memilih Sekolah Pada Siswa SMP Negeri 1 Krayan Kalimantan Timur." Jurnal SPIRITS 4(2):47-53.

Fitriantie, Reza, Sulistyarini, and Parijo. 2014. "Motivasi Siswa Bersekolah Di SMK Negeri 1 Tebas Kecamatan Tebas." Jurnal Pendidikan Dan Pembelajaran Khatulistiwa 3(5):1-16.

Lestari, Sri, and Moh Mudzakkir. 2016. "Rasionalitas Memilih Sekolah Menengah Kejuruan (SMK) (Studi Kasus Di Desa Dingil Kecamatan Jatirogo Kabupaten Tuban)." 4(3):1-6.

Maulana, Fajar, Wakhinuddin Wakhinuddin, M. Giatman, and Edidas Edidas. 2020. "Analysis of Factors Forming the Students' Business Interests At Vocational High School 2 Payakumbuh." Jurnal Pendidikan Teknologi Kejuruan 3(1):10-13.

Maulana, Fakhrian Harza. 2015. "Pengaruh Motivasi Intrinsik, Motivasi Ekstrinsik Dan Komitmen Organsasi Terhadap Kinerja Karyawan Pada Bank BTN Kantor Cabang Malang." 22(1):1-8.

Sitompul, Lenia. 2018. "Meningkatkan Pemahaman Perencanaan Karir Melalui Layanan Bimbingan Karir Di Sekolah Dengan Menggunakan Media Gambar Pada Siswa Kelas Ix-1 Smp Negeri 1 Gebang Tahun 2017-2018." Jurnal Tabularasa PPS UNIMED 51(1):51.

Wardani, Silvia Yula, and Rischa Pramudia Trismani. 2017. "Efektifitas Layanan Informasi Untuk Meningkatkan Pemahaman Karier Siswa." Gusigang 3(2):207-12.

Wiharja, Hery. 2018. "Pengaruh Pengalaman Praktek Kerja Industry Dan Internal Locus Of Control Terhadap Kesiapan Kerja Siswa SMK." Jurnal FamilyEdu 5(1):48-54.

Wiharja, Hery, Sri Rahayu, and Evi Rahmiyati. 2020. "Pengaruh Self Efficacy Terhadap Kesiapan Kerja Mahasiswa Pendidikan Vokasi." VOCATECH: Vocational Education and Technology Journal 2(1):11-18. 